\title{
Lumen
}

Selected Proceedings from the Canadian Society for Eighteenth-Century Studies

\section{Gibbon at Lausanne}

\section{Brian Norman}

Volume 13, 1994

URI : https://id.erudit.org/iderudit/1012529ar

DOI : https://doi.org/10.7202/1012529ar

Aller au sommaire du numéro

Éditeur(s)

Canadian Society for Eighteenth-Century Studies / Société canadienne d'étude du dix-huitième siècle

ISSN

1209-3696 (imprimé)

1927-8284 (numérique)

Découvrir la revue

Citer cet article

Norman, B. (1994). Gibbon at Lausanne. Lumen, 13, 137-143.

https://doi.org/10.7202/1012529ar d'utilisation que vous pouvez consulter en ligne.

https://apropos.erudit.org/fr/usagers/politique-dutilisation/ 


\section{Gibbon at Lausanne}

This paper aims to make a fresh assessment of the significance of Edward Gibbon's stay at Lausanne in 1763/4, using his contemporary Journal, his letters and his Memoirs of more than a quarter of a century later. It confirms in general the views of Georges Bonnard in his essay published in 1944 in French on the importance of Gibbon's second stay at Lausanne on the formation of the historian, ${ }^{1}$ but this paper argues that Gibbon became more historically minded at that time without knowing which aspects of Roman history would engage his attention in the future. The moment of conception of The Decline and Fall of the Roman Empire had not yet arrived but, to change the metaphor, the realization of his vocation was dawning.

Gibbon arrived at Lausanne for the second time on 25 May 1763 on the second stage of his Grand Tour. He had waited until after the signing of peace preliminaries with France in November 1762 and until the termination of his active militia service before undertaking his long anticipated visit to Italy. His first stop was in Paris where he had introductions to the leading names of the Enlightenment in France. Captivated by this intellectual emancipation, he took exactly four months to reach the shores of Lake Geneva from leaving England.

He had first arrived in Lausanne for an enforced stay of five years in 1753 at the age of sixteen after he had shocked his father by revealing his conversion to Roman Catholicism. Then he had to learn to live without a servant in a strange world where he could not understand the language. The food at M. Pavillard's, the Protestant pastor who was his tutor confessor, was bad and not enough. 'My condition,' Gibbon recalled in his Memoirs, 'seemed as destitute of hope as it was devoid of pleasure.'

Ten years later, however, he was an experienced man of the world, proud of his literary connections, and the author of The Essay on the Study of Literature written in the language that had been foreign to him in 1753. This time he was staying as a 'pensionnaire,' one of several young gentlemen of good birth doing the Grand Tour, in the household of Henri Crousaz, seigneur of Mézery, who had a town house on the fashionable 
rue de Bourg and a château in the hilly countryside to the north-west of Lausanne.

And yet, at the age of twenty-six, Gibbon was still financially dependent on his father. Before his departure from England he had negotiated an allowance that would support him during an absence of two years. After incurring heavy expenses during his stay in Paris, he had intended to pass only two or three months in Lausanne to renew friendships and to prepare for his tour of Italy. Engaged in the social round and his studies, he found eleven months slipped by in Lausanne and he was uncertain whether he could afford to continue his tour until in March 1764 he received a letter from his father which assured him of sufficient funds. The amount was not particularly generous but at least he could proceed on an honest footing, as he confided to his Journal. ${ }^{3}$

Gibbon's mornings in Lausanne were spent usually in reading and in composing a description of Italy in ancient times. Frequent dinner parties starting at mid-day were followed by promenades into the late afternoon. Supper parties in his friends' houses sometimes included amateur theatricals and more often games of whist. Occasionally he was involved in heavy drinking bouts with his male friends which affected his ability to study the next morning. Worse still there were disturbances in the streets, on one occasion involving Gibbon's compatriots in a show of arms by the night watch. Gibbon led a spirited protest before the magistrates which resulted, luckily for the young Englishmen, in a reprimand for the watch. ${ }^{4}$ In the summer the Mézerys' country château was much more used while in the winter months the local gentry resided in their town houses and took to a fairly intensive round of balls and carefully rehearsed theatrical presentations. Gibbon attended the plays and joined in the card games but excused himself from dancing. In his Memoirs, he remembers the parties where fifteen or twenty young unmarried ladies would laugh and sing and play at cards amidst a crowd of young men of mixed nationalities and where the invisible line between liberty and licentiousness was never transgressed. ${ }^{5}$ This picture is rather more sharply focused in his contemporary Journal where he reveals his liking for social banter and flirtation which remained with him throughout his adult life.

Gibbon's reading in Lausanne included works in Latin on the topography of Rome, the geography of Italy and the science of medals. In the middle of September 1763 he began a treatise on ancient Rome by Famiano Nardini translated from the Italian into Latin by Jacob Tollius which was included in a Treasury of Roman Antiquities collected by Professor Graevius of Utrecht and published in twelve volumes in folio at Utrecht and at Leyden from 1694 to $1699 .{ }^{6}$ Making notes often amounting to critical essays in his Journal, Gibbon read some 340 pages of double 
columns about the topography of classical Rome on fourteen out of sixteen days from September 17 to October 2. Eleven days later he began another major work also in Latin on the geography of ancient Italy by Philip Cluvier in two volumes in folio, published at Leyden in $1624 .{ }^{7}$ This book has been described as one of the most indigestible books of the Renaissance: Gibbon himself thought Cluvier's method and style were confused. He completed reading its 1338 pages on December 3, making entries about it in his Journal on thirty eight of the fifty-two days from October 13 to December 3. A third major work in Latin which he read and took notes on during the months of February, March and April 1764 was about ancient medals. During his visit to Paris, he had visited the Cabinet du Roi and noted the sad decline in the æsthetic appeal of ancient medals after the ages of Alexander and Augustus. He regretted that he was so new to this 'belle science. ${ }^{8}$ In Lausanne he went on to read Addison's Dialogues upon the Usefulness of Ancient Medals and that now inspired him to turn to a more weighty work by Ezechiel Spanheim. It was first published in Rome in 1664; Gibbon used a later edition in two volumes in quarto published in Amsterdam in 1671. ${ }^{9}$ Again there are daily entries about its contents in his Journal but this time there are gaps of a week and of nearly four weeks when he laid it aside for his own composition of a description of Italy. He completed the 914 pages of Spanheim's work in twenty one days between 12 February and 11 April 1764.

These examples of his studies show Gibbon's ability to read up to one hundred pages of Latin in a morning and to comment critically on the content, registering ideas which were to be used for his Italian tour. Later, the names of these authorities were to appear in the footnotes of The Decline and Fall of the Roman Empire.

Gibbon was reading more widely than this, however. From August 1763 to April 1764, he read and commented upon Juvenal's Satires, the letters of Baron de Bielfeld about the courts of Germany including Frederick the Great's, Strabo's Geography of Italy in a Latin translation of 1587, the letters of Mary Wortley Montagu, Ovid's Fasti, Rousseau's Letter to D'Alembert on Spectacles, Voltaire's Treatise on Toleration and M. de la Condamine's Journal of a Tour of Italy.

Moreover, Gibbon systematically went through the quarterly literary review published in Amsterdam from 1728 to 1753 called La Bibliothèque Raisonnée des Ouvrages des Savans de l'Europe, finishing the fiftieth and last volume on 21 March 1764. It contained full accounts and criticisms of new works, helping to keep Gibbon abreast of relatively recent historical works.

Gibbon's main composition in these months, apart from his Journal, was his description of Italy in ancient times which has survived in The 
Miscellaneous Works published after his death by Lord Sheffield under the title of Nomina, gentesque antiquæ Italix. ${ }^{10}$ This work is best described in Gibbon's own words in a letter to his stepmother of 6 August 1763. There he wrote that he would like to stay in Lausanne over the winter because he was engaged in a considerable work

Which will be a most usefull [sic] preparation to my tour of Italy which I shall not be able to finish sooner. It is a description of the ancient Geography of Italy, taken from the Original writers. If I go into Italy with a work of that kind tolerably executed, I shall carry every where about with me an accurate and lively idea of the Country, and shall have nothing to do but to insert in their proper places my own observations as they tend either to confirm, to confute or to illustrate what I have met with in books. ${ }^{11}$

Gibbon appears to have started this work in the summer of 1763 in the Château de Mézery in an effort to concentrate on his future plans, away from the distractions of Lausanne society. There are intermittent references in the Journal to writing a page or two of it a day during August to October 1763 and then there is a gap. Yet in reviewing the past year at the beginning of January 1764, Gibbon could write that he had composed much of his description, believing it to be well stocked with information. Nevertheless, there is a reference to considerable further work on it during January and references to its composition become more numerous in the weeks preceding his departure. On March 17, we have a picture of Gibbon going up to the library of the Academy of Lausanne to research into the history of the early peoples of Italy before writing about them on the following day. ${ }^{12}$ Finally on March 29, he reported in his Journal that he had collected in ninety two pages a rich fund of information which his future reading and tour of Italy would enable him to arrange into a complete description. ${ }^{13}$

How hard did Gibbon work in those months of social entertainment and distractions at Lausanne? In his Memoirs, we have a detailed account of the comprehensive course of study in the Latin classics that he had undertaken during his first stay in Lausanne. Of his second visit, Gibbon jokingly boasted some twenty five years later, that few travellers more completely armed and instructed have ever followed the footsteps of Hannibal! ${ }^{14}$ There were not perhaps the extensive reading projects of his earlier stay. There are signs of Gibbon's continuing reliance on Pavillard for seeking out the books that would be of most benefit for his tour of Italy. The volumes by Nardini were obtained for him by Pavillard from the public library in Geneva. ${ }^{15}$ And yet we see in his study of medals, an independent mind at work on what was for him a new aspect of Rome's material decline which he had found on his own initiative. And we see 
in his essays committed to his Journal and to a separate series published by Sheffield in the Miscellaneous Works ${ }^{16}$ the mind of the historian already formulating the ideas of a history of Rome.

Yet at this stage of his life Gibbon was undergoing emotional strain of an intensity that took him by surprise and at times interrupted his studies. He had left Lausanne in 1758 as a lover seeking his father's permission to marry Suzanne Curchod, the daughter of a Protestant pastor in the Pays de Vaud. Family opposition and recognition of the impracticality of marrying a foreigner without a secure income had led him to forget the physical and conversational attractions of Suzanne. On his return to the shores of Lake Geneva in 1763 he was surprised that Suzanne was still interested in him, hoping that his love for her was still alive in spite of his filial obligations. It was a shock for Gibbon. In his Journal, he exclaims: 'Fille dangereuse et artificielle!' How could her letter to him of September 1763 have so much candour and sentiment after what he had heard of her social successes in Lausanne during his absence ${ }^{17}$ There was a genuine misunderstanding between them. Gibbon had misinterpreted the date of her letter, Suzanne referring to September as the seventh month of the year according to an old practice. In any case, however, Gibbon had decided on his course. He must maintain his independence. He went out of his way to show his indifference by flaunting his interest in other young ladies - especially 'la petite femme' of M. de Seigneux. It was not an agreeable aspect of Gibbon's social behaviour and other female friends of his warned him of the danger to his reputation. But his method if hard was effective and before Suzanne's departure from Lausanne a fortnight before his own they were already conversing with emotional detachment. His independence in this respect was firmly established the following year when Suzanne was safely married to $M$. Necker. When Gibbon visited her splendid new residence in Paris on the last stage of his Grand Tour, he could replace the badinage with a much more worthwhile friendship that lasted all their lives, Mme. Necker outliving Gibbon by less than four months.

On his own departure from Lausanne in April 1764, Gibbon was accompanied as far as Geneva by the Seigneur de Mézery and three other companions from Lausanne, in addition to William Guise, the son of a Gloucestershire baronet who was to remain with him throughout his tour of Italy. It was like being a pilgrim of old, with a group of well-wishers celebrating his departure for Rome on the first stage of a journey which would confirm Gibbon in his calling. It was a heroic period of Gibbon's life but he showed his characteristic sobriety in his carefully composed assessment of his second stay in Lausanne in his Journal for 17 April $1764 .{ }^{18}$ There was a sharp contrast of mood with his earlier departure in 1758. Then he had left Lausanne as a lover looking forward 
to an early return. Now he was aware of the worth of a new friend, the Englishman Holroyd who was later to become his family business adviser and as Lord Sheffield his very capable literary executor. He was conscious of the great debt of gratitude that he owed to his former tutor Pavillard. He had again been welcomed into a society which he now remembered for its playfulness and its preference for whist to conversation. Now he was aware too of a greater intellectual challenge ahead. For these years 1763 and 1764 were in fact the crucial years when Gibbon's interests took a definite turn which would eventually in the next two decades lead him to become the unrivalled historian of his century.

That was not his inevitable destiny when he had started his Grand Tour. Then he had seen himself as about to enter the drawing rooms of Europe with a newly won reputation as a gentleman of letters. In his subsequent studies in Lausanne described in detail in his Journal we can see his critical faculty focusing on such historical facts as the crossing of the Alps by Hannibal, the size and population of classical Rome, the navigability of the Tiber. Juvenal's Satires and Ovid's Fast $i$ were read for their insight into the Roman character. He was beginning to imagine the publication of his notes. They would form a narrative less confusing than Cluvier's - a clear, methodical and interesting narrative based on original authorities rather than a string of obscure quotations. As yet he was fascinated more by the greatness of Rome than by its decline. He would make use of the recent research into the monuments of the Etruscans and of Herculaneum. He would put everything in order, casting a philosophical eye over the country and its inhabitants after describing its surface. Men of letters would be able to appreciate such writing. In his Memoirs he was later to overdramatize the moment in Rome when it seemed to him that the idea of his history had first started to his mind. A new resolution had already formed in his mind in Lausanne. It was to develop much further in the succeeding years, but as he followed in Hannibal's footsteps, 'not on the back of an elephant; but on a light osier seat, in the hands of the dexterous and intrepid chairmen of the Alps, ${ }^{19}$ he too was embarked on a campaign; it would not lead to frustration and defeat but to the realization and ultimate deliverance of The Decline and Fall of the Roman Empire.

BRIAN NORMAN

Gillingham, Kent 


\section{Notes}

1 G.A. Bonnard, 'L'importance du deuxième séjour de Gibbon à Lausanne dans la formation de l'historien' in Mélanges d'histoire et de littérature offerts à M. Charles Gilliard (Lausanne: F. Rouge \& Cie S. A., 1944), pp. 401-20.

2 Memoirs of my Life, ed. G. A. Bonnard (London: Nelson, 1966), p. 70.

3 Le Journal de Gibbon à Lausanne, ed. G. A. Bonnard (Lausanne: F. Rouge \& Cie S. A., 1945), p. 242.

4 Ibid., p. 7, and Appendix I.

5 Memoirs, op. cit., p. 130.

6 Journal, op. cit., p. 42.

7 Journal, op. cit., p. 89.

8 Paris Journal included in Miscellanea Gibboniana, ed. G. R. de Beer, G. A. Bonnard and L. Junod (Lausanne, 1952).

9 Journal, op. cit., p. 213.

10 The Miscellaneous Works of Edward Gibbon, Esq. (London: Murray, 1814), 4: 157-326.

11 The Letters of Edward Gibbon, ed. J. E. Norton (London: Cassell, 1956), 1: 153-54.

12 Journal, op. cit., p. 242.

13 Ibid., p. 249.

14 Memoirs, op. cit., p. 132.

15 Journal, op. cit., p. 42.

16 The Miscellaneous Works of Edward Gibbon, Esq. (London: Murray, 1796), 2: 313-404.

17 Journal, op. cit., p. 51.

18 Journal, op. cit., p. 263.

19 Memoirs, op. cit., p. 133. 